\title{
Menopoz Dönemindeki Diyabetik Kadınlarda Yaşanılan Semptomların Yaşam Kalitesi Parametreleri Üzerindeki Etkisinin İncelenmesi (Prospektif Tek Grup Çalışma)
}

\author{
Ayşegül KOÇ ${ }^{1} \bowtie$, Betül ÇAKMAK ${ }^{\oplus}$, Birgül GENÇ² $\bullet$ \\ ${ }^{1}$ Ankara Yıldırım Beyazıt Üniversitesi, Sağlık Bilimleri Fakültesi, Hemşirelik Bölümü, Ankara, Türkiye \\ ${ }^{2}$ Ankara Şehir Hastanesi, Ankara, Türkiye \\ Bu makaleye yapılacak atıf: Koç A ve ark. Menopoz dönemindeki diyabetik kadınlarda yaşanılan semptomların yaşam kalitesi parametreleri üzerindeki etkisinin incelenmesi \\ (Prospektif Tek Grup Çalışma). Turk J Diab Obes 2021;2: 137-145.
}

\begin{abstract}
ÖZ
Amaç: Bu araştırma, menopoza giren diyabetli kadınların deneyimledikleri ortak semptomların yaşam kalitesi parametreleri üzerindeki etkisini belirlemek amacıyla gerçekleştirilmiştir.

Gereç ve Yöntemler: Prospektif tek grup çalışma olarak gerçekleştirilen araştırmanın örneklemini diyabet tanısı almış, klimakterik dönemde olan 50-70 yaş aralığında olan 106 kadın hasta oluşturmuştur. Verilerin toplanmasında, 'Demografik anket formu', 'Diyabet geçmiş öykü formu' ve 'UTIAN yaşam kalitesi Ölçeği' kullanılmıştır. Verilerin analizinde ise tanımlayıcı istatistikler hesaplanmış, değişkenler arasındaki anlamlılıkların belirlenmesinde $t$ testi, ANOVA Mann Whitney U ve Kruskal Wallis testinin analizleri gerçekleștirilmiştir.

Bulgular: Klimakterik dönemde olan diyabetli kadınların \%52,8’i 45-60, \%43,4’ü 60 yaş üstü olup büyük bölümünün (\%70,8) ilkokul ve altı eğitim aldığı belirlenmiştir. Hastaların diyabet tanı süreleri (\%71,1) 6-20 yıl arasında değişmektedir. Çalışmaya katılan kadınların \%45,3’ünün diyabet hastalığına ilişkin komplikasyonlardan en az birini yaşadıkları belirlenmiştir. Kadınlar arasında bekâr olan, eğitim düzeyi yüksek, disparoni ve inkontinans yaşamayanlar ve diyabet tedavisi olarak Oral Antidiyabetik kullananların yaşam kaliteleri diğer kadınlardan anlamlı olarak daha yüksektir bulunmuştur. ( $\mathrm{p}<0,05)$. Hastaların yaşadıkları semptom sayılarının toplamının ölçek toplam ve alt boyut puanları ile diyabet tanı süresi, HgA1c değerleri, açlık ve tokluk kan glukoz değerleri arasında anlamlı ilişki bulunamamıştır $(\mathrm{p}>0,05)$.

Sonuç: Araştırmamız ile eğitim durumu, medeni durum, disparoni, diyabet tedavisi tipi ve diyabet komplikasyonlarının varlığının, hastaların yaşam kalitesini etkilediği belirlenmiştir. Klimakterik dönemdeki diyabetik hastanın gereksinimlerinin ve problemlerinin doğru tanımlanarak yaşam kalitelerinin yükseltilmesinde eğitim, danışmanlık, takip gibi etkili hemşirelik yaklaşımlarının kullanılmasının gerekli olduğu önerilmektedir.
\end{abstract}

Anahtar Sözcükler: Diyabet, Menopoz, Kadın, Yaşam kalitesi, Hemşirelik

\section{Investigation of the Effects of Symptoms on Quality of Life in Diabetic Women During Menopause (Prospective Single Group Study)}

\begin{abstract}
Aim: This research was carried out to determine the effect of common symptoms experienced by diabetic women entering menopause on quality of life parameters.

Material and Methods: The sample of the study, which was carried out as a prospective single-group study, consisted of 106 female patients between the ages of 50-70 who were diagnosed with diabetes and were in the climacteric period. 'Demographic questionnaire form', 'Diabetes past history form' and 'UTİAN quality of life Scale' were used for data collection.
\end{abstract}

ORCID: Ayșegül Koç / 0000-0003-1179-5550, Betül Çakmak / 0000-0002-8122-2101, Birgül Genç / 0000-0002-0775-9752 
Results: It was determined that $52.8 \%$ of the diabetic women in the climacteric period were $45-60$ years old , $43.4 \%$ were over 60 years old, and most of them (70.8\%) received primary school or less education. The diabetes diagnosis period of the patients $(71.1 \%)$ varies between 6-20 years. It was determined that $45.3 \%$ of the women participating in the study experienced at least one of the chronic complications of diabetes. Among women, the quality of life of those who are single, highly educated, who do not experience dyspareunia and incontinence, and those who use Oral Antidiabetic (OAD) as a diabetes treatment is significantly higher than other women. $(p<0,05)$. There was no found significant relationship between the total number of symptoms experienced by the patients, scale total and sub-dimension scores, duration of diabetes, $\mathrm{HgA} 1 \mathrm{c}$ values, fasting and postprandial blood glucose values ( $\mathrm{p}>0,05$ ).

Conclusion: Since diabetes and menopause contain common symptoms, this situation negatively affects the lives of women. It is very important to use effective nursing approaches such as education, counseling, and follow-up in improving the quality of life of the patients by correctly identifying the symptoms that occur with menopause in diabetic female patients.

Keywords: Diabetes mellitus, Menopause, Woman, Quality of life, Nursing

\section{Gíriș}

Bireylerin yaşamlarını olumsuz etkileyen en önemli kronik hastalıklardan biri olan diyabetin görülme oranı her geçen yll artarak devam etmekte olup ülkemizde de ortalama 7 milyonu aşkın diyabet hastasının bulunduğu ve bu sayının toplam erişkin nüfusunun \%15'ine denk geldiği bildirilmektedir (1). Diyabetin artış nedenleri arasında; ortalama yaşam süresinin yükselmesi, kentleşmeye bağlı yaşam tarzı değişiklikleri, fiziksel hareketsizlik ve beslenme değişiklikleri sayılmaktadır (2). Uluslararası diyabet federasyonuna (IDF) verilerine göre diyabet görülme oranının artmasıyla birlikte önümüzdeki 30 yıl içinde diyabet hastası bireylerin sayısının 1,5 katına çıkacağı bildirilmektedir (3).

Diyabet hastalarında süreç boyunca hem akut hem de kronik olarak birçok semptom görülmektedir. Busemptomlar, huzursuzluk ve sıkıntı hissi, yorgunluk hissi, sıcak basması ve fenalık hissi, terleme, kol ve bacak eklemlerinde ağrılar, unutkanlık, çabuk sinirlenme-öfkelenme-ağlama, uyku düzensizliği, ilgi-istek azalması, el ve ayaklarda soğukluk ve uyuşukluk olarak bildirilmektedir. Bu belirtilerin menopozlu kadınlarda da olduğu ve diyabetli kadınlarla ortak payda da buluştukları görülmektedir. $(4,5)$

Kadınların menopoz süreci boyunca deneyimledikleri menopozal semptomlar ve östrojen hormonunun koruyucu etkisinin azalması ile birlikte kadınlar kronik hastalıklara karşı daha savunmasız hâle gelmektedir (6). Menopozla birlikte hiperinsülinemi ve bozulmuş glukoz toleransıyla beraber abdominal obezite de doğru orantılı olarak artış göstermektedir. Östrojen replasmanı yapılan postmenopozal hastalarda açlık insülin düzeylerinin düşük olması ve glukoz yüklemesine daha düşük insülin yanıtlarının oluşması sebebiyle bu durum metabolik değişikliklerde östrojen eksikliğinin rol oynadığı fikrini güçlendirmektedir. Yap1lan bir çalışmada östrojen replasmanı uygulanan hastalarda uygulanmayanlara göre diyabet görülme oranının \%20 daha az olduğu bildirilmektedir (7). Ayrıca artan yaş ile birlikte menopozlu kadınlarda diyabet görülme sıklığının da arttığı bildirilmektedir. Menopoz sonrası dönemle birlikte over hormonlarının etkinliğini kaybetmesiyle kadınlarda meydana gelen metabolik ve fizyolojik değişikliklerle birlikte diyabet oluşma riski artmakta ve kadınlarda menopozla birlikte artık daha sık görülen diyabet semptomlarının şiddeti kadının yaşamında daha etkili olarak yer almaktadır (7). Özellikle menopoz ve diyabete yönelik görülen etkiler ortak semptomlar içermesi sebebiyle zaman zaman karıştırılabilir (8). Böylece semptomların yönetilmesi zor ve karmaşık hâle gelebilmektedir. Menopoz dönemindeki kadınların yaşadıkları semptomlara yönelik yaşam kalitelerini değerlendiren bir çalışmada kadınların semptomları şiddetli düzeyde yaşadıkları ve yaşam kalitelerinin olumsuz olarak etkilendiği bildirilmiştir (9).

Hemşirelerin, diyabetik ve menopozal dönemde olan kadınların yaşam kalitesi düzeyini artırmak adına doğru hemşirelik bakımını verme sorumluluğu bulunmaktadır. $\mathrm{Bu}$ nedenle hastanın semptomlarını doğru analiz edebilmek, kökenini tespit edebilmek bu süreçte hemşirenin sunacağ bakım hizmetini planlamasında oldukça önemli bir yer tutar. Kadınlarda diyabet ve menopoz arasındaki etkileşim incelendiği yeterli literatüre ulaşılamamıştır. Diyabetli kadınların çoğunluğunun 50 yaş üzeri olması ve menopoz geçişi sırasında ve sonrasında teşhis edildiği için, bu son derece yaygın olan iki koşulun etkilerine yönelik çalışmalar sınırlı sayıdadır (10). Araştırma, bir devlet kurumuna başvuran, menopoza giren diyabetli kadınların deneyimledikleri ortak semptomların yaşam kaliteleri üzerindeki etkisini belirlemek amacıyla gerçekleştirilmiştir.

\section{GEREÇ ve YÖNTEMLER}

\section{Araştırmanın Tipi}

Araştırma prospektif tek grup çalışma olarak gerçekleştirilmiştir.

\section{Araştırmanın Evreni ve Örneklemi}

Araştırma, Haziran 2018- Nisan 2019 tarihleri arasında bir Ankara Yıldırım Beyazıt Üniversitesi Atatürk Eğitim ve 
Araştırma Hastanesinin Endokrin ve Metabolizma kliniğinde ayaktan diyabet tanısı almış, araştırmaya katılmayı kabul eden, iletişim engeli olmayan ve klimakterik dönemde olan 106 kadın hasta oluşturmuştur. Araştırma süresi içinde kriterlere uyan, araştırmaya katılmayı kabul eden tüm hastalar araştırmaya kabul edilmiştir.

Veri Toplama Araçları

\section{Demografik Anket Formu}

Araştırma verilerinin toplanmasında araştırmacı tarafından gerekli literatür taranarak hazırlanmış olan hastaların yaş, medeni durum, sosyoekonomik durum, hastalık süresi, tedavi yaklaşımları, sigara kullanımı vb. durumlarını belirlemek amaciyla hazırlanan demografik anket formu kullanılmıştır $(11,12)$.

\section{Diyabet Geçmiş Öykü Formu (DGÖF)}

Araştırmada, hastaların diyabet ve menopoza özgü olarak yaşayabilecekleri ortak semptomların belirlenmesine yönelik verilerin toplanmasında araştırmacı tarafından gerekli literatür taranarak hazırlanmış olan 'Diyabet Geçmiş Öykü Formu (DGÖF)' kullanılmıştır (11, 13, 14). 27 maddeden oluşan bu yarı yapılandırılmış anket formunda sıcak basması, terleme, el ayak uyuşması, iştahsızlık, ağız kuruluğu, inkontinans yaşama durumu, vajinal kuruluk gibi hem diyabet hem de menopoza girmiş kadınlarda ortak olarak görülen semptomlar belirtilmiş olup, semptomu yaşayan hastalar '1' yaşamayan hastalar ise '0' puan almıştır. Çalışma sonunda her hastanın aldığı puan toplanarak ölçek puanları ile arasındaki analiz sonuçları değerlendirilmiştir.

\section{UTİAN Yaşam kalitesi ölçeği}

Araştırmada, ülkemizde geçerlik ve güvenilirliği Abay ve Kaplan tarafından yapılmış klimakterik kadınlara özgü
UTİAN Yaşam kalitesi ölçeği kullanılmıştır. Ölçek beşli likert tipte olup, Emosyonel yaşam kalitesi (1., 11., 12., 13., 15., 20. soru maddeleri; $\min =6 \max =30$ puan), Cinsel yaşam kalitesi (4., 5., 14. soru maddeleri; $\min =3 \max =15$ puan), Meslek-iş yaşam kalitesi (2., 3., 6., 17., 18., 19., 23. soru maddeleri; $\min =7$ max $=35$ puan) ve Sağlık yaşam kalitesi (7., 8., 9., 10., 16., 21., 22. soru maddeleri; $\min =7 \mathrm{max}=35$ puan) olmak üzere dört alt boyuta sahiptir. Ölçeğin cronbach alfa güvenirlik katsayısı 0,88 olarak bulunmuştur. Ölçeğin alt boyutlarının cronbach alfa güvenirlik katsayıları ise sırasıyla; Emosyonel yaşam kalitesi cronbach alfa güvenirlik katsayıs1 0,78, Cinsel yaşam kalitesi cronbach alfa güvenirlik katsayısı 0,76, Meslek-iş yaşam kalitesi cronbach alfa güvenirlik katsayısı 0,75 , Sağlık yaşam kalitesi cronbach alfa güvenirlik katsayısı 0,79 olarak belirlenmiştir. Ölçekten alınabilecek en düşük puan 23 , en yüksek puan ise 115 'tir. Ölçek ve alt boyut puanın artması yaşam kalitesinin yükseldiğini göstermektedir (15).

\section{Verilerin Toplanması}

Araştırma verileri hastalar ile kurumun diyabet eğitim hemşiresi odasında yüz yüze görüşülerek toplanmıştır. Her bir görüşme ortalama olarak 10-20 dakika arası sürmüştür. Görüşme sırasında öncelikli olarak hastanın onayı alınmış ardından mahremiyeti sağlanarak görüşmeler gerçekleștirilmiştir. Verilerin toplanması sırasında herhangi bir engel ile karşılaşılmamıștır.

\section{Araştırmanın Sınırlılıkları}

Araştırmanın en önemli sınırlılığ tek hastanede yapılmış olmasidir.

\section{Araştırmanın Etik Yönü}

Çalışmanın gerçekleştirilebilmesi amacıyla gerekli etik kurul izni (19.05.2018-karar no:35) alınmış olup, çalışma-

Tablo 1: Bazı Sosyodemografik ve Hastalığa İlişkin Özelliklerin Dağılımı

\begin{tabular}{|c|c|c|c|c|c|c|c|}
\hline Kategori & & $\mathbf{n}$ & $\%$ & Kategori & & $\mathbf{n}$ & $\%$ \\
\hline \multirow{3}{*}{ Yaş } & $30-45$ yaş arası & 4 & 3,8 & \multirow{2}{*}{ Sigara içme durumu } & Evet & 11 & 10,4 \\
\hline & 45-60 yaş arası & 56 & 52,8 & & Hayır & 95 & 89,6 \\
\hline & 60 yaş üstü & 46 & 43,4 & \multirow{3}{*}{ Ekonomik durum } & Gelir giderden fazla & 9 & 8,5 \\
\hline \multirow{2}{*}{ Medeni durum } & Evli & 92 & 86,8 & & Gelir gidere eşit & 49 & 46,2 \\
\hline & Bekâr & 14 & 13,2 & & Gelir giderden az & 48 & 45,3 \\
\hline \multirow{2}{*}{ Meslek } & Ev hanımı & 100 & 94,3 & \multirow{3}{*}{ En uzun yaşanan yer } & İl merkezi & 72 & 67,9 \\
\hline & Memur & 6 & 5,7 & & İlçe merkezi & 20 & 18,9 \\
\hline \multirow{5}{*}{ Eğitim durumu } & Okur yazar değil & 22 & 20,8 & & Köy & 14 & 13,2 \\
\hline & İlkokul-okur yazar & 53 & 50,0 & \multirow{4}{*}{ Diyabet tanısı süresi } & $0-5 \mathrm{yll}$ & 18 & 17,0 \\
\hline & Ortaokul & 16 & 15,1 & & $6-10 \mathrm{yll}$ & 39 & 36,8 \\
\hline & Lise & 8 & 7,5 & & $11-20 \mathrm{yll}$ & 37 & 34,9 \\
\hline & Üniversite & 7 & 6,6 & & 21 ve üstü & 12 & 11,3 \\
\hline
\end{tabular}


nın amacı ve kendilerinden alınacak bilgilerin gizli kalacağ 1 açılandıktan sonra hastalardan yazılı onam alınmıştır.

\section{Araştırma Verilerinin Değerlendirilmesi}

İstatistiksel analizler, SPSS (IBM SPSS Statistics 24) adlı paket programı kullanılarak yapılmıştır. Bulguların yorumlanmasında frekans tabloları ve tanımlayıcı istatistikler kullanılmıștır. Verilerin normal dağılıma uygunluğu Kolmogorov -Smirnov ve Shapiro-Wilk testi ile incelenmiştir. Normal dağılıma uygun ölçüm değerleri için parametrik yöntemler kullanılmıştır. Parametrik yöntemlere uygun şekilde, iki bağımsız grubun ölçüm değerleriyle karşılaştırilmasında "Independent Sample-t" test (t-tablo değeri); üç veya daha fazla bağımsız grubun ölçüm değerleriyle karşılaştırılmasında "ANOVA" test (F-tablo değeri) istatistikleri kullanılmıştır. Normal dağılıma uygun olmayan ölçüm değerleri için parametrik olmayan yöntemler kullanılmıştır. Parametrik olmayan yöntemlere uygun şekilde, iki bağımsız grubun ölçüm değerleriyle karşılaştırılmasında "Mann-Whitney U" test (Z-tablo değeri); üç veya daha fazla bağımsız grubun ölçüm değerleriyle karşılaştırılmasında "Kruskal-Wallis" test ( $\chi 2$-tablo değeri) istatistikleri kullanılmıştır. Normal dağılıma sahip olmayan ölçüm değerlerinin birbirleriyle ilişkisinin incelenmesinde "Spearman" korelasyon katsayısı kullanılmıştır. G*Power 3.0.10 programı yardımıyla Post hoc yapılan çalışmanın güç analizi; \%5 hata payı, \%80 güç ile toplamda 106 örnek sayısı yeterli bulunmuştur.

\section{BULGULAR}

$\mathrm{Bu}$ araştırma bulguları araştırma kapsamına alınan diyabetik bireylerde genellenebilir. Araştırmaya katılan kadınların \%52,8'i 45-60, \%43,4'ü 60 yaş üstü ve $\% 3,8$ 'i 30-45 yaş aralığındadır. Bu kuruma başvuran hastaların \%86,8’i evli olup \%13,2'si bekârdır. Kadınların \%94'ü ev hanımı, \%5,7'si ise memur olarak çalışmaktadır. Çalışmaya katılan kadınların eğitim durumlarına bakıldığında büyük bölümünün $(\% 70,8)$ ilkokul-okur yazar ve okur yazar olmadığı belirlenmiştir. Kadınların en uzun yaşadıkları yerin il merkezi olduğu $(\% 67,9)$, ekonomik durumlarını çoğunlukla gelir gidere eşit $(\% 46,2)$ ve az $(\% 45,3)$ olarak tanımladıkları belirlenmiştir. Hastaların diyabet tanı süreleri çoğunlukla (\%71,1) 6-20 yll arasında değişmektedir.

Kuruma başvuran hastaların diyabet tedavisi, eğitimi alma ve diyabet ile ilişki bilgi sahibi olma durumlarına ilişkin veriler Tablo 2'de sunulduğu gibidir. Hastaların \%10,4 ü diyabet hastalığına yönelik olarak bitkisel tamamlayıcı yöntemler kullandığını belirtmiş olup hastaların \%39.4'ü idrar inkontinansı sorunu yaşadığını belirtmiştir. Kadınların \%34,9'ünün 30-45 yaş aralığında, \%55.7'si 45-60 yaş aralığında doğal menopoza girmiş oldukları \% 9,4'ünün ise histerektomi ameliyatı sonrası menopoza girdiklerini bildirilmiştir. Kadınlardan son üç haftalarını değerlendirmeleri istendiğinde ise $\% 43,4$ 'ü kendisini mutsuz- neşesiz $\% 31,1$ ' $\mathrm{i}$ nötr, \%25.5'i ise mutlu-neşeli hissettiğini ifade etmiştir.

Tablo 3'de hastaların bazı demografik özellikleri ve ölçek toplam ve alt boyut puanlarına ilişkin verilerin dağılımı belirtilmiştir. Çalışmamızda hastaların medeni durumları ve cinsel alt boyut puan ortalamaları arasında anlaml fark bulunmuştur. $(\mathrm{p}=0,000)$. Bekârların cinsel alt boyut puanları evlilerin puanlarından daha yüksektir.

Çalışmamızda hastaların eğitim durumları ve mesleki alt boyut puan ortalamaları arasında anlamlı fark bulunmuştur. $(p=0,049)$. Kadınların eğitim durumları yükseldikçe mesleki yaşam kalitesi puanları da yükselmektedir.

Tablo 2: Hastaların diyabet tedavisi, eğitimi alma ve diyabet ile ilişki bilgi sahibi olma durumlarına ilişkin verilerin dağılımı

\begin{tabular}{|c|c|c|c|c|c|c|c|}
\hline \multirow{2}{*}{ Kategori } & & $\mathbf{n}$ & $\%$ & \multicolumn{2}{|l|}{ Kategori } & $\mathbf{n}$ & $\%$ \\
\hline & Tip 1 DM & 3 & 2,8 & \multirow{2}{*}{$\begin{array}{l}\text { Glukometre cihazına } \\
\text { sahip olma }\end{array}$} & Evet & 88 & 83,0 \\
\hline \multirow[t]{2}{*}{ Diyabet tipi } & Tip 2 DM & 103 & 97,2 & & Hayır & 18 & 17,0 \\
\hline & OAD & 38 & 35,8 & \multirow{2}{*}{$\begin{array}{l}\text { Glukometre cihazını } \\
\text { kullanmayı bilme }\end{array}$} & Evet & 69 & 65,1 \\
\hline \multirow{3}{*}{ Diyabet tedavisi } & İnsülin & 33 & 31,1 & & Hayır & 37 & 34,9 \\
\hline & OAD+İnsülin & 34 & 32,1 & \multirow[b]{2}{*}{$\begin{array}{l}\text { Glukometre cihaz } \\
\text { kullanımı yorumlama }\end{array}$} & Evet & 67 & 63,2 \\
\hline & $\begin{array}{l}\text { OAD+İnsülin+insülin } \\
\text { pompası cihazı kullanımı }\end{array}$ & 1 & 0,9 & & Hayır & 39 & 36,8 \\
\hline \multirow{6}{*}{$\begin{array}{l}\text { İnsülin } \\
\text { kullanma } \\
\text { durumu }\end{array}$} & Günde 1 kez & 8 & 7,5 & \multirow{5}{*}{$\begin{array}{l}\text { Diyabet } \\
\text { Komplikasyonu } \\
\text { varlığı }\end{array}$} & Nöropati & 6 & 5,7 \\
\hline & Günde 2 kez & 24 & 22,6 & & Retinopati & 13 & 12,3 \\
\hline & Günde 3 kez & 20 & 18,9 & & Nefropati & 8 & 7,5 \\
\hline & Günde 4 kez & 17 & 16,0 & & 2 komplikasyon & 13 & 12,3 \\
\hline & Günde 5 kez & 1 & $(0,9)$ & & 3 komplikasyon & 8 & 7,5 \\
\hline & Kullanmiyor & 36 & 34,0 & & & & \\
\hline
\end{tabular}


Tablo 3: Hastaların bazı demografik özellikleri ve ölçek toplam ve alt boyut puanlarına ilişkin verilerin dağılımı

\begin{tabular}{|c|c|c|c|c|c|c|c|c|c|c|}
\hline \multirow{3}{*}{$(n=106)$} & \multicolumn{2}{|c|}{ UTİAN Toplam puanı } & \multicolumn{2}{|c|}{ Duygusal Alt boyut } & \multicolumn{2}{|c|}{ Cinsel Alt boyut } & \multicolumn{2}{|c|}{ Mesleki Alt boyut } & \multicolumn{2}{|c|}{ Sağlık Alt boyut } \\
\hline & \multirow{2}{*}{ Ort. \pm S.S. } & Median & \multirow{2}{*}{ Ort. \pm S.S. } & Median & \multirow{2}{*}{ Ort. \pm S.S. } & Median & \multirow{2}{*}{ Ort. \pm S.S. } & \multirow{2}{*}{$\begin{array}{c}\text { Median } \\
\text { Min-Max }\end{array}$} & \multirow{2}{*}{ Ort. \pm S.S. } & \multirow{2}{*}{$\begin{array}{c}\text { Median } \\
\text { Min-Max }\end{array}$} \\
\hline & & Min-Max & & Min-Max & & Min-Max & & & & \\
\hline \multicolumn{11}{|l|}{ Yaş } \\
\hline \multirow{2}{*}{$30-45$ yaş arası } & \multirow{2}{*}{$73,25 \pm 12,99$} & 72,50 & \multirow[b]{2}{*}{$3,41 \pm 0,50$} & 3,33 & \multirow[b]{2}{*}{$3,41 \pm 0,41$} & 3,33 & \multirow{2}{*}{$3,21 \pm 0,72$} & 3,35 & \multirow{2}{*}{$2,85 \pm 1,12$} & 2,92 \\
\hline & & $60,00-88,00$ & & $3,00-4,00$ & & $3,00-4,00$ & & $2,29 / 3,86$ & & $1,57 / 4,00$ \\
\hline \multirow{2}{*}{ 45-60 yaş arası } & \multirow{2}{*}{$72,00 \pm 12,49$} & 71.50 & \multirow{2}{*}{$3,14 \pm 0,54$} & 3,16 & \multirow{2}{*}{$3,11 \pm 1,16$} & 3,01 & \multirow{2}{*}{$3,27 \pm 0,74$} & 3,28 & \multirow{2}{*}{$2,97 \pm 1,03$} & 2,85 \\
\hline & & $39,00-118,00$ & & $1,83-4,00$ & & $1,00-6,00$ & & $1,86 / 4,86$ & & $1,43 / 9,43$ \\
\hline \multirow{2}{*}{$60-70$ yaş arası } & \multirow{2}{*}{$70,80 \pm 8,86$} & 71.50 & \multirow{2}{*}{$3,12 \pm 0,50$} & 3,00 & $342+122$ & 3,02 & & 3,21 & & 2,85 \\
\hline & & $48,00-91,00$ & & $2,00-4,67$ & $3,42 \pm 1,22$ & $1,00-6,00$ & $3,10 \pm 0,69$ & $1,57-4,71$ & $2,86 \pm 0,49$ & $1,57-4,43$ \\
\hline $\mathbf{x}^{2} ; \mathbf{p}$ & 0,112 & 0,945 & 1,372 & 0,504 & 1,471 & 0,479 & 0,814 & 0,666 & 0,142 & 0,932 \\
\hline Mede & & & & & & & & & & \\
\hline & & 70,50 & & 3,08 & & 3,00 & & 3,28 & & 2,85 \\
\hline $\mathbf{E}$ & 7,0 & $39,00-118,00$ & 0,54 & $1,83-4,67$ & & $1,00-6,00$ & & $1,57-4,86$ & 9 & $1,43-9,43$ \\
\hline Bel $>$ & & 77,00 & & 3,16 & & 5,33 & & 3,14 & & 2,92 \\
\hline Bekar & $/ 4,92$ & $61,00-87,00$ & $\pm 0,40$ & $2,50-4,00$ & $4,69 \pm 1,4 /$ & $2,00-6,00$ & $0, / 2$ & $2,00-4,14$ & 0,32 & $2,00-3,29$ \\
\hline$Z(t) ; p$ & $-1,72$ & $; 0,085$ & $-0,577$ & $; 0,564$ & $-3,679$ & 0,000 & 0,661 & 0,510 & $-0,356$ & 0,722 \\
\hline Eğitim Durumu & & & & & & & & & & \\
\hline Okur-yazar & & 70,50 & & 3,00 & & 3,00 & & 3,14 & & 3,00 \\
\hline değil & 70.77 & $52,00-87,00$ & 0,50 & $2,50-4,50$ & 3,2 & $1,00-6,00$ & 3 , & $1,57-4,29$ & & $2,43-4,00$ \\
\hline İlkokul-okur & $70.09+11$ & 71,00 & & 3,16 & & 3,33 & & 3,00 & & 2,85 \\
\hline & $70.09 \pm 11.3$ & $39,00-97,00$ & 4 & $1,83-4,67$ & & $1,00-6,00$ & & $1,86-4,71$ & 61 & $1,43-4,43$ \\
\hline Ort? & $7575+1306$ & 73,5 & $305+0-40$ & 3,08 & $358+127$ & 3,00 & 0.55 & 3,35 & $339+163$ & 3,00 \\
\hline Orta & $15.15 \pm 13.90$ & $57,00-118,00$ & $3,05 \pm 0,40$ & $2,33-3,83$ & $3,58 \pm 1,21$ & $2,33-6,00$ & $3,2 / \pm 0,55$ & $2,14-4,14$ & $3,39 \pm 1,03$ & $2,57-9,43$ \\
\hline $\mathbf{I i}$ & 73.12 & 72 & 3 & 3,08 & & 2,83 & & 3,64 & & 2,85 \\
\hline Lise & 13.12 & $62,00-92,00$ & 69 & $2,17-4,00$ & 2 & $1,00-4,00$ & 31 & $2,57-4,86$ & 38 & $2,29-3,43$ \\
\hline & & 73 & & 3,16 & & 3,33 & & 3,71 & & 2,57 \\
\hline & & $65,00-83,00$ & & $2,33-4,00$ & & $2,67-6,00$ & & $3,00-4,71$ & & $1,57-3,00$ \\
\hline$x^{2}(F) ; p$ & 0,930 & $; 0,450$ & 0,901 & 0,924 & 2,365 & 0,669 & 9,518 & 0,049 & 8,621 & ;0,71 \\
\hline
\end{tabular}

\section{Ekonomik Durum}

\begin{tabular}{|c|c|c|c|c|c|c|c|c|c|c|}
\hline \multirow{2}{*}{$\begin{array}{l}\text { Gelir giderden } \\
\text { fazla }\end{array}$} & \multirow{2}{*}{$69,55 \pm 9,65$} & 68,00 & \multirow{2}{*}{$2,90 \pm 0,48$} & 3,00 & \multirow{2}{*}{$2,96 \pm 0,80$} & 3,00 & \multirow{2}{*}{$3,36 \pm 0,85$} & 3,00 & \multirow{2}{*}{$2,80 \pm 0,32$} & 2,85 \\
\hline & & $55,00-88,00$ & & $2,17-3,67$ & & $1,33-3,67$ & & $2,43-4,86$ & & $2,43-4,86$ \\
\hline \multirow{2}{*}{$\begin{array}{l}\text { Gelir gidere } \\
\text { eşit }\end{array}$} & \multirow{2}{*}{$73,04 \pm 11,94$} & 72,00 & \multirow{2}{*}{$3,18 \pm 0,50$} & 3,16 & \multirow{2}{*}{$3,28 \pm 1,24$} & 3,33 & \multirow{2}{*}{$3,32 \pm 0,65$} & 3,42 & \multirow{2}{*}{$2,97 \pm 1,14$} & 2,85 \\
\hline & & $48,00-118,00$ & & $2,00-4,67$ & & $1,00-6,00$ & & $2,14-4,71$ & & $1,43-9,43$ \\
\hline \multirow{2}{*}{$\begin{array}{l}\text { Gelir giderden } \\
\text { az }\end{array}$} & \multirow{2}{*}{$70,35 \pm 10,12$} & 71,50 & \multirow{2}{*}{$3,15 \pm 0,55$} & 3,08 & \multirow{2}{*}{$3,29 \pm 1,17$} & 3,00 & \multirow{2}{*}{$3,04 \pm 0,74$} & 3,14 & \multirow{2}{*}{$2,89 \pm 0,45$} & 2,85 \\
\hline & & $39,00-92,00$ & & $1,83-4,50$ & & $1,00-6,00$ & & $1,57-4,71$ & & $1,57-4,00$ \\
\hline $\mathbf{x}^{2}(\mathrm{~F}) ; \mathrm{p}$ & \multicolumn{2}{|c|}{0,$884 ; 0,416$} & \multicolumn{2}{|c|}{1,$805 ; 0,406$} & \multicolumn{2}{|c|}{0,$106 ; 0,948$} & \multicolumn{2}{|c|}{2,$419 ; 0,298$} & \multicolumn{2}{|c|}{0,$370 ; 0,831$} \\
\hline \multicolumn{11}{|c|}{ Diyabet Komplikasyonu Varlığı } \\
\hline \multirow{2}{*}{$\begin{array}{l}\text { Komplikasyon } \\
\text { yok }\end{array}$} & \multirow{2}{*}{$73,41 \pm 11,60$} & 73,00 & \multirow{2}{*}{$3.17 \pm 0,54$} & 3,16 & \multirow{2}{*}{$3.46 \pm 1,27$} & 3,33 & \multirow{2}{*}{$3.28 \pm 0,62$} & 3,35 & \multirow{2}{*}{$2.99 \pm 1,06$} & 2,85 \\
\hline & & $48,00-118,00$ & & $2,00-4,67$ & & $1,00-6,00$ & & $1,86-4,71$ & & $1,43-9,43$ \\
\hline \multirow{2}{*}{ Nöropati } & \multirow{2}{*}{$63,83 \pm 13,55$} & 66,50 & \multirow{2}{*}{$2,66 \pm 0,50$} & 2,83 & \multirow{2}{*}{$2,83 \pm 1,09$} & 2,83 & 062 & 3,07 & 73 & 2,71 \\
\hline & & $39,00-78,00$ & & $1,83-3,17$ & & $1,00-4,33$ & $2,88 \pm 0,62$ & $2,00-3,57$ & , , & $1,57-3,71$ \\
\hline & & 67,00 & & 3,50 & & 3,00 & & 2,85 & & 2,71 \\
\hline Retin & $67,76 \pm 8,09$ & $52,00-80,00$ & 0,56 & $2,33-4,00$ & 21 & $1,00-6,00$ & $2,91 \pm 0,75$ & $1,57-3,86$ & $2, / 3 \pm 0,41$ & $2,00-3,43$ \\
\hline Nefronati & $7037+1142$ & 68,50 & $318+033$ & 3,08 & -046 & 3,16 & $298+083$ & 2,85 & +0.55 & 2,85 \\
\hline & $70,3 / \pm 11,42$ & $60,00-97,00$ & $3,18 \pm 0,33$ & $3,00-4,00$ & $3,20 \pm 0,46$ & $2,67-4,00$ & $2,98 \pm 0,83$ & $1,86-4,57$ & $2,96 \pm 0,55$ & $2,29-4,14$ \\
\hline 2 & & 68,00 & & 3,16 & & 3,00 & & 2,71 & & 2,85 \\
\hline komplikasyon & 68,5 & $55,00-88,00$ & 3,1 & $2,50-3,67$ & 3,1 & $1,00-6,00$ & 81 & $1,86-4,71$ & 20 & $2,57-3,14$ \\
\hline 3 & & 73,5 & & 2,83 & & 3,16 & & 3,85 & & 2,92 \\
\hline komplikasyon & ,70 & $68,00-92,00$ & $3,04 \pm 0,60$ & $2,17-4,00$ & $3,00 \pm 0,95$ & $1,33-4,00$ & $=0,81$ & $3,00-4,86$ & $2,94 \pm 0,32$ & $2,57-3,43$ \\
\hline
\end{tabular}

\begin{tabular}{llllll}
\hline $\mathbf{x}^{\mathbf{2}}(\mathbf{F}) ; \mathbf{p}$ & 9,$236 ; 0,100$ & 5,$052 ; 0,410$ & 4,$473 ; 0,484$ & $\mathbf{1 5 , 0 8 9 ; 0 , 1 0}$ & 1,$729 ; 0,885$ \\
\hline
\end{tabular}


Tablo 3 devam

\begin{tabular}{|c|c|c|c|c|c|c|c|c|c|c|}
\hline \multicolumn{11}{|c|}{ Disparoni Yaşama Durumu } \\
\hline \multirow{2}{*}{ Yaşıyor } & \multirow{2}{*}{$76,35 \pm 13,25$} & 75,5 & \multirow{2}{*}{$3,14 \pm 0,56$} & 3,16 & \multirow{2}{*}{$3,76 \pm 1,33$} & 3,33 & \multirow{2}{*}{$3,47 \pm 0,80$} & 3,50 & \multirow{2}{*}{$3,12 \pm 1,55$} & 3,00 \\
\hline & & $57,00-118,00$ & & $2,17-4,50$ & & $1,00-6,00$ & & $2,14-4,86$ & & $1,43-9,43$ \\
\hline \multirow{2}{*}{ Yaşamıyor } & \multirow{2}{*}{$70,40 \pm 10,13$} & 70,50 & \multirow{2}{*}{$3,14 \pm 0,52$} & 3,00 & \multirow{2}{*}{$3,14 \pm 1,11$} & 3,00 & \multirow{2}{*}{$3,13 \pm 0,68$} & 3,21 & \multirow{2}{*}{$2,87 \pm 0,55$} & 2,85 \\
\hline & & $39,00-97,00$ & & $1,83-4,67$ & & $1,00-6,00$ & & $1,57-4,71$ & & $1,57-4,43$ \\
\hline$Z(t) ; p$ & \multicolumn{2}{|c|}{$-1,754 ; 0,079$} & \multicolumn{2}{|c|}{$-0,49 ; 0,961$} & \multicolumn{2}{|c|}{$-2,019 ; 0,043$} & \multicolumn{2}{|c|}{$-1,473 ; 0,141$} & \multicolumn{2}{|c|}{$-0,239 ; 0,811$} \\
\hline \multicolumn{11}{|c|}{ Diyabet Tedavisi Tipi } \\
\hline \multirow{2}{*}{ OAD } & \multirow{2}{*}{$72,36 \pm 9,47$} & 73,00 & \multirow{2}{*}{$3,09 \pm 0,51$} & 3,00 & \multirow{2}{*}{$3,37 \pm 1,27$} & 3,33 & \multirow{2}{*}{$3,40 \pm 0,57$} & 3,57 & \multirow{2}{*}{$2,83 \pm 0,56$} & 2,85 \\
\hline & & $48,00-92,00$ & & $2,00-4,00$ & & $1,00-6,00$ & & $1,86-4,71$ & & $1,57-4,43$ \\
\hline \multirow{2}{*}{ İnsülin } & \multirow{2}{*}{$71,36 \pm 13,89$} & 72 & \multirow{2}{*}{$3,15 \pm 0,48$} & 3,16 & \multirow{2}{*}{$3,17 \pm 1,21$} & 3,00 & \multirow{2}{*}{$2,99 \pm 0,70$} & 3,14 & \multirow{2}{*}{$3,13 \pm 1,30$} & 3,00 \\
\hline & & $39,00-118,00$ & & $1,83-4,00$ & & $1,00-6,00$ & & $1,57-4,71$ & & $1,43-9,43$ \\
\hline \multirow{2}{*}{ OAD+İnsülin } & \multirow{2}{*}{$70,77 \pm 9,51$} & 68 & \multirow{2}{*}{$3,19 \pm 0,57$} & 3,16 & & 3,00 & & 3,00 & & 2,71 \\
\hline & & $57,00-92,00$ & & $2,17-4,67$ & 13 & $1,00-6,00$ & 83 & $1,86-4,86$ & 31 & $1,86-3,57$ \\
\hline $\mathbf{x}^{2}(\mathrm{~F}) ; \mathbf{p}$ & 1,301 & 0,522 & 0,325 & 0,850 & 0,388 & 0,824 & 7,285 & 0,026 & 1,$671 ;$ & 0,434 \\
\hline İnkontinans & Imu & & & & & & & & & \\
\hline Yesiver & $6842+1066$ & 68,5 & $303+052$ & 3,00 & 18 & 3,00 & 075 & 3,00 & & 2,85 \\
\hline Iaşiyor & $00,42 \pm 10,00$ & $39,00-92,00$ & $3,03 \pm 0,52$ & $1,83-3,83$ & $2,90 \pm 1,18$ & $1,00-6,00$ & $3,06 \pm 0, / 5$ & $1,86-4,71$ & $2,83 \pm 0,56$ & $1,43-4,00$ \\
\hline & & 72,50 & & 3,16 & & 3,33 & & 3,42 & & 2,85 \\
\hline raşaminyor & 15,50 & $52,00-118,00$ & $5,21 \perp 0,52$ & $2,17-4,67$ & $5,4 J \perp 1,13$ & $1,00-6,00$ & $5,27 \perp 0,00$ & $1,57-4,86$ & 2,7010,97 & $1,57-9,43$ \\
\hline$Z(t) ; p$ & $-2,410$ & ;0,018 & $-1,393$ & 0,164 & $-1,66$ & 0,097 & $-1,94$ & 0,052 & $-0,464$ & 0,643 \\
\hline
\end{tabular}

${ }^{*}$ Normal dağılıma sahip olan iki, üç veya daha fazla bağımsız grubun karşılaştırılmasında 't testi' ve “ANOVA” testi kullanılmıştır.

${ }^{*}$ Normal dağılıma sahip olmayan iki, üç veya daha fazla bağımsız grubun karşılaştırılmasında "Mann-Whitney U” test (Z-tablo değeri ve "KruskalWallis" testi kullanılmıştır

Çalışmamızda kuruma başvuran hastaların diyabet komplikasyonu yaşama durumları ve mesleki alt boyut puan ortalamaları arasında anlamlı fark bulunmuştur. $(\mathrm{p}=0,010) .3$ komplikasyonu da yaşayan bireylerin mesleki yaşam kalitesi puanları retinopati ve 2 komplikasyon yaşayan bireylerden daha yüksek bulunmuştur. Oral Antidiyabetik OAD kullanan hastaların mesleki yaşam kaliteleri ise insülin kullananlardan daha yüksek bulunmuştur. ( $\mathrm{p}=0,026)$.

Disparoni yaşamayan kadınların cinsel alt boyut puan ortalamaları yaşayanlardan daha yüksek bulunmuştur. $(\mathrm{p}=0,043)$. Çalışmamızda hastaların inkontinans yaşama durumları ve utian puanları arasinda anlamlı fark bulunmuştur. $(p=0,018)$. İnkontinans yaşamayan diyabetli kadınların yaşam kalitesi daha yüksektir.

Hastaların diyabete özgü bazı özellikleri ve ölçek toplam ve alt boyut puanlarına ilişkin verilerin birbiriyle ilişkilerinin incelenmesinde (Tablo 4'te) yaşanan semptom sayılarının toplamının ölçek toplam ve alt boyut puanları, Diyabet hastalık süresi, HgAlc değerleri, açlık ve tokluk kan şekeri değerleri arasında ilişki bulunamamıştır.

\section{TARTIŞMA}

Yaşamı olumsuz etkileyen en önemli kronik hastalıklardan biri olan diyabetin görülme oranı her geçen yıl artarak devam etmektedir. Özellikle menopoza giren kadınlarda görülen menopoz ve diyabet semptomlarının karıştırılma- s1 ve ortak etkilerin kontrol altına alınamamasıyla birlikte hastaların yaşadıkları sağlık problemleri zamanla daha da karmaşık hâle gelmekte ve yaşam kaliteleri olumsuz etkilenmektedir. $(1,9)$.

Çalışmamızda diyabetli kadınların eğitim düzeylerinin yükselmesiyle birlikte mesleki yaşam kalitelerinin de yükseldiği belirlenmiştir. Ülkemizde Koç ve ark. tarafından diyabet tanısıyla izlenen hastalarda yaşam kalitesi ve ilişkili faktörlerin incelenmesi amacıyla gerçekleştirilen bir çalışmada

Tablo 4: Hastaların diyabete özgü bazı özellikleri ve ölçek toplam ve alt boyut puanlarına ilişkin verilerin birbiriyle ilişkilerinin incelenmesi

\begin{tabular}{lcc}
\hline & \multicolumn{2}{c}{ Yaşanan semptom sayısı } \\
\hline & $\mathbf{r}$ & $\mathbf{p}$ \\
\hline Cinsel alt boyut & 0,136 & 0,164 \\
\hline Mesleki alt boyut & $-0,010$ & 0,919 \\
\hline Sağlık alt boyut & $-0,002$ & 0,984 \\
\hline Duygusal alt boyut & $-0,178$ & 0,078 \\
\hline Toplam (UTAIN) & 0,022 & 0,822 \\
\hline DM hastalık süresi (yıl) & $-0,117$ & 0,232 \\
\hline HgA1c & 0,111 & 0,256 \\
\hline Açlık kan şekeri & 0,118 & 0,230 \\
\hline Tokluk kan şekeri & $-0,004$ & 0,964 \\
\hline
\end{tabular}


hastaların \%19,7'sinin hangi diyabet tipine sahip olduğunu bilmediği, bilmeyen hastaların ise $\% 73,3$ 'ü ilkokul ve altı eğitim düzeyine sahip olduğu bildirilmektedir (16). Özellikle tedavi sürecinde hastaya önemli bir sorumluluk yükleyen diyabet hastalığına sahip bireylerin eğitim durumları sebebiyle süreç boyunca yeterince aktif rol almamalarının yaşam kalitelerini olumsuz etkileyebileceği düşünüldüğünde araştırmamızın literatür ile uyumlu olduğu söylenebilir.

Menopoza girmiş diyabetli kadınlardan disparoni yaşamayanların cinsel yaşam kaliteleri, disparoni yaşayanlardan daha yüksek bulunmuştur. Kadın cinsel hayatında yaşlanma ve menopozal geçişle birlikte meydana gelen vajen ve serviksde kan akımı ve sekresyonunun azalmasiyla otonom nöropati aracılığıyla cinsel uyarılmanın azalması ve eşlik eden hormonal değişiklikler, özellikle de diyabet varlığı cinsel disfonksiyonu oluşturan en önemli risk faktörleridir (17). Ayrica bu dönemde hormonlarda meydana gelen farklilıklarla birlikte duygusal bozuklukların görülmesi, bireylerin cinsel doyumlarını da olumsuz etkilemektedir (18). Literatürde menopoz sonrası dönemde kadınların cinsel ilișki sırasında ağrı deneyimledikleri menopoz döneminde olan diyabetli kadınların ise seksüel fonksiyon bozuklukları yaşadıkları bildirilmektedir $(19,20)$. Diyabet hastalığı da zamanla oluşturduğu vasküler dejenerasyonlar, uyarılma azlığ bakıldığında çalışmamız literatür ile uyumludur. Kadınların diyabet ve menopozun etkisiyle yaşadıkları disparoni durumununun cinsel yaşam kalitelerine olan olumsuz etkisini azaltmak amacıyla hemşirelerin klinik ortamlarda hastalarının cinsel yaşamlarına yönelik daha detaylı sorular sormaları ve konuya ilişkin doğru sağlık profesyonellerine yönlendirmelerinin sorunun çözümü açısından önemli olacağı söylenebilir.

Ülkemizde Taşkaya tarafından gerçekleștirilen bir çalışmada insülin kullanan bireylerin OAD kullananlara göre acil servislere daha fazla başvurdukları ve hastaneye yattıkları belirlenmiştir (22). Koç ve ark. tarafından yapılan bir başka çalışmada ise insülin kullananların \%45,5'inin insülin iğnesinin acıttığını, \%52,4’ü insülinin kilo aldırdığını düşündüğü belirtilmiştir (16). Çalışmamızda OAD kullanan diyabetli kadınların mesleki yaşam kalitelerinin insülin kullananlardan daha yüksek olduğu bulunmuştur. Literatüre bakıldığında bu sonuçların bireylerin yaşam kalitelerini olumsuz etkileyebileceği düşünülebilir. Diyabet tedavisinin etkilerinin değerlendirildiği diğer çalışmalara bakıldığında tedaviye uyumu artırması, hastanede yatış süresini azaltmaya yönelik etkileri sebebiyle insülin kullanan hastaların yaşam kalitesine olumlu etkilerinin olduğunu gösteren çalışmalar da bulunmaktadır $(23,24)$. Bu nedenle konuyla ilgili yapılacak başka çalışmalara ihtiyaç olduğu düşünülmektedir.
Diyabetik hastalarda metabolik kontrolün sürdürülmesi hastaların yaşam kalitelerine olumlu olarak katkı sağlamaktadır (25). Zaman içinde hastalık yükünün artması ve metabolik kontrolün sağlanamaması ile birlikte gelişen komplikasyonlar hastaların yaşam kalitelerini olumsuz etkilemektedir $(26,27)$. Araştırmamızda kadınların yaşadıkları komplikasyon sayısının artmasıyla mesleki yaşam kalitelerinin de arttığı belirlenmiştir. Hastaların deneyimledikleri komplikasyonların yaşam kalitesine etkisini inceleyen bir araștırmada ise komplikasyonların artmasıyla birlikte hastaların iş hayatlarının da olumsuz olarak etkilendiği bildirilmektedir (28). Araştırmamız sonucunun literatürden farklı çıkmasının kadınların yaşadıkları komplikasyonlar ile birlikte baş etme becerilerinin daha da artması sebebiyle geliştiği düşünülmektedir.

Klimakterik dönemle birlikte meydana gelen vazomotor, ürogenital, psikososyal etkilerin sebebiyle meydana gelen en önemli semptomlardan biri de inkontinans olarak belirtilmektedir (29). Çalışmamızda inkontinans yaşamayan kadınların yaşam kalitesi yaşayan kadınlardan daha yüksek bulunmuștur. Ülkemizde 18 yaş üstü kadınlarda üriner inkontinansın sıklığı ve etkileyen faktörlerin belirlenmesi için gerçekleştirilen bir çalışmada diyabetin bir risk faktörü olduğu belirtilmektedir(30). Diyabetli bireylerde meydana gelen ürolojik komplikasyonların yaşam kalitesine olan etkisinin değerlendirildiği bir çalışmada, inkontinansın yaşam kalitesini olumsuz etkilediği bildirilmektedir (31). Literatür sonuçları çalışmamızla uyumlu olmakla birlikte kadınların hem fiziksel beden algılarını, hem de sağlık durumlarını olumsuz yönde etkileyen bir faktör olan inkontinansın önlenmesine yönelik olarak hemşirelerin çalışma ortamlarında hem eğitici hem de bakım verici rollerini kullanarak hastalara pelvik egzersizler konusunda bilgilendirmeler, bireysel hijyenin sağlanmasına yönelik girişimler ve hastanın beden algısında olumsuz düşüncelere sebep olan faktörlerin belirlenmesine yönelik olumlu görüşmeler yapmasının sürece olumlu katkı sağlayacağı düşünülmektedir.

Teșekkür

Çalışmaya katılmaya gönüllü olan tüm hastalarımıza ve araştırma yapılmasına izin veren Ankara Atatürk Eğitim ve Araştırma Hastanesi yönetimine teşekkür ederiz.

Yazarların Makaleye Katkı Beyanı

Çalışma konsepti-tasarımı: Ayşegül Koç, Veri toplama: Betül Çakmak, Birgül Genç, Veri analizi ve yorumlama: Betül Çakmak, Yazı taslağı: Ayşegül Koç, Betül Çakmak, İçeriğin eleştirel incelenmesi: Ayşegül Koç, Betül Çakmak, Son onay ve sorumluluk: Ayşegül Koç, Betül Çakmak, Birgül Genç.

\section{Çıkar Çatışması}

Yazarların beyan edecek herhangi bir çıkar çatışmaları yoktur. 


\section{Finansal Destek}

Bu çalışmanın yapılabilmesi için herhangi bir finansal destek alınmamıştır

\section{Etik Kurul Onayı}

Çalışmanın gerçekleştirilebilmesi amacıyla gerekli etik kurul izni Ankara Yıldırım Beyazıt Üniversitesi Etik Kurulundan (19.05.2018-karar no:35) alınmış olup, çalışmanın amacı ve kendilerinden alınacak bilgilerin gizli kalacağı açıklandıktan sonra hastalardan yazılı onam alınmıştır.

\section{Hakem Değerlendirmesi}

Kör hakemlik süreci sonrası yayınlanmaya uygun bulunmuş ve kabul edilmiştir.

\section{KAYNAKLAR}

1. Satman I, Omer B, Tutuncu Y, Kalaca S, Gedik S, Dinccag N, Karsidag K, Genc S, Telci A, Canbaz B, Turker F, Yilmaz T, Cakir B, Tuomilehto J; TURDEP-II Study Group. Twelveyear trends in the prevalence and risk factors of diabetes and prediabetes in Turkish adults. Eur J Epidemiol. 2013;28(2):169180.

2. Talaz D, Kızılcı S. Tip 2 diyabet riski ve hastalık sürecinde uykunun rolü. Dokuz Eylül Üniversitesi Hemşirelik Fakültesi Elektronik Dergisi. 2015;8(3).

3. Federation I. IDF Diabetes Atlas Eighth Edition 2017.

4. Diabetes Mellitus ve Komplikasyonlarının Tanı, Tedavi ve İzlem Kılavuzu Türkiye Endokrinoloji ve Metabolizma Derneği. 2018. [Erişim tarihi 17.03.2021].

5. Özdemir İ, Hocaoğlu Ç, Koçak M, Ersöz ÖH. Tip 2 diyabetes mellituslu hastalarda yaşam kalitesi ve ruhsal belirtiler. Düşünen Adam The Journal of Psychiatry and Neurological Sciences. 2011;24:128-138.

6. Daan NM, Fauser BC. Menopause prediction and potential implications. Maturitas. 2015;82(3):257-265.

7. Yağmur S. Kadınların Bazı Özelliklerinin ve Menopoz Semptomlarının Menopozal Tutuma Etkisi. Malatya: İnönü Üniversitesi; 2018. [yayınlanmamış yüksek lisans tezi]

8. Appiah D, Winters SJ, Hornung CA. Bilateral oophorectomy and the risk of incident diabetes in postmenopausal women. Diabetes Care. 2014;37(3):725-733.

9. Avc1 S. Menopoz dönemindeki kadınlarda menopoz semptomlarının yaşam kalitesine etkisi. İstanbul: Halic University; 2013. [yayınlanmamış yüksek lisans tezi]

10. Karvonen-Gutierrez CA, Park SK, Kim C. Diabetes and Menopause. Curr Diab Rep. 2016;16(4):20.

11. Gawlik NR, Bond MJ. The role of negative affect in the assessment of quality of life among women with type 1 diabetes mellitus. Diabetes Metab J. 2018;42(2):130-136.

12. Abubakari AR, Cousins R. Do work characteristics influence quality of life among people with diabetes? Diabetic Medicine. 2018;35(Sup1):178.
13. Muharam R, Setiawan MW, Ikhsan M, Rizkinya HE, Sumapraja K. Depression and its link to other symptoms in menopausal transition. Middle East Fertility Society Journal. 2018;23(1):27-30.

14. Emre N. Diyabetik hastalarda uyku kalitesi ile anksiyete ve depresyon durumlarının değerlendirilmesi. TJCL. 2019;10(3): 283-288.

15. Abay H, Kaplan S. Validation and reliability of the Turkish utian quality-of-life Scale in postmenopausal women. Menopause. 2016;23(4):425-32.

16. Koç EM. Diyabet tanısıyla izlenen hastalarda yaşam kalitesi ve ilişkili faktörlerin incelenmesi: Türkiye için bir pilot çalışma. Konuralp Tip Dergisi. 2015;7(2):76-82.

17. Baldassarre M, Alvisi S, Berra M, Martelli V, Farina A, Righi A, Meriggiola MC. Changes in vaginal physiology of menopausal women with type 2 diabetes. J Sex Med. 2015;12(6):1346-1355.

18. Mazzilli R, Imbrogno N, Elia J, Delfino M, Bitterman O, Napoli A, Mazzilli F. Sexual dysfunction in diabetic women: Prevalence and differences in type 1 and type 2 diabetes mellitus. Diabetes Metab Syndr Obes. 2015;8:97-101.

19. Avis NE, Colvin A, Karlamangla AS, Crawford S, Hess R, Waetjen LE, Brooks M, Tepper PG, Greendale GA. Change in sexual functioning over the menopausal transition: Results from the Study of Women's Health Across the Nation. Menopause. 2017;24(4):379-390.

20. Cortelazzi D, Marconi A, Guazzi M, Cristina M, Zecchini B, Veronelli A, Cattalini C, Innocenti A, Bosco G, Pontiroli AE. Sexual dysfunction in pre-menopausal diabetic women: Clinical, metabolic, psychological, cardiovascular, and neurophysiologic correlates. Acta Diabetol. 2013;50(6):911917.

21. Giraldi A, Kristensen E. Sexual dysfunction in women with diabetes mellitus. J Sex Res. 2010;47(2):199-211.

22. Taşkaya S. Diyabet hastalarının tedaviye uyum düzeyleri ile sağlık hizmeti kullanımı ve yaşam kalitesini etkileyen faktörler. 2014. [yayınlanmamış yüksek lisans tezi]

23. Aagren M, Luo W, Moës E. Healthcare utilization changes in relation to treatment intensification with insulin aspart in patients with type 2 diabetes. Data from a large US managedcare organization. J Med Econ. 2010;13(1):16-22.

24. Çıtıl R, Günay O, Elmalı F, Öztürk Y. Diyabetik hastalarda tıbbi ve sosyal faktörlerin yaşam kalitesine etkisi. Erciyes Tıp Dergisi. 2010;32(4):253-264.

25. Green AJ, Fox KM, Grandy S; SHIELD Study Group. Selfreported hypoglycemia and impact on quality of life and depression among adults with type 2 diabetes mellitus. Diabetes Res Clin Pract. 2012;96(3):313-318.

26. Rubin RR, Peyrot M. Quality of life and diabetes. Diabetes Metab Res Rev. 1999;15(3):205-218.

27. Sothornwit J, Srisawasdi G, Suwannakin A, Sriwijitkamol A. Decreased health-related quality of life in patients with diabetic foot problems. Diabetes Metab Syndr Obes. 2018;11:35-43. 
28. Gore M, Brandenburg NA, Dukes E, Hoffman DL, Tai KS, Stacey B. Pain severity in diabetic peripheral neuropathy is associated with patient functioning, symptom levels of anxiety and depression, and sleep. J Pain Symptom Manage. 2005;30(4):374-385.

29. Kim HK, Kang SY, Chung YJ, Kim JH, Kim MR. The recent review of the genitourinary syndrome of menopause. J Menopausal Med. 2015;21(2):65-71.
30. Terzi H. 18 yaş üstü kadınlarda üriner inkontinans sıklığı ve etkileyen faktörler. Ege Tip Dergisi. 2013;52(1):15-19.

31. Jacobson AM, Braffett BH, Cleary PA, Dunn RL, Larkin ME, Wessells H, Sarma AV; DCCT/EDIC Research Group. Relationship of urologic complications with health-related quality of life and perceived value of health in men and women with type 1 diabetes: the Diabetes Control and Complications Trial/Epidemiology of Interventions and Complications (DCCT/EDIC) cohort. Diabetes Care. 2015;38(10):1904-1912. 